\title{
An efficient market? Going public in London, 1891-1911
}

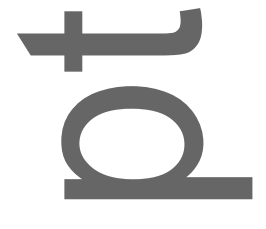

$\square$

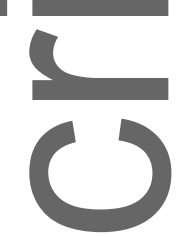

Sturla Fjesme

Oslo Metropolitan University

Neal Galpin

Monash University, Melbourne

Lyndon Moore

University of Melbourne

Corresponding author: lyndon.moore@unimelb.edu.au

\section{Abstract}

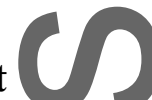

There have been claims that British capital was not well deployed in Victorian Britain. There was, allegedly, a lack of support for new and dynamic companies in comparison to the situation in Germany and the United States. We find no evidence to support these claims. The London Stock Exchange welcomed young, old, domestic and foreign firms. It provided funds to firms in old, existing industries as well as patenting firms in "new-tech" industries at similar costs of eapital. If investors did show a preference for older and foreign firms it was because those firms offered investors better long-run performance. In addition, we show some evidence that investors who worked in the same industry and lived close to the firm going public were allotted more shares in high-quality initial public offerings (IPOs).

\section{Acknowledgements}

We thank Oyvind Bohren, François Derrien, Espen Eckbo, Lorenzo Garlappi, Will Gornell, Bruce Grundy, Leslie Hannah, Alexander Ljungqvist, Oyvind Norli, John Turner, William Wilhelm and Li-Anne Woo for helpful comments. Seminar participants at ANU, BI Norwegian Business School, Bond University, NHH Norwegian School of Economics, Oslo Business School, Queen's University of Belfast, Tilburg University, University of Bonn, University of British Columbia, University of Melbourne, University of Stavanger, University of Virginia, the 2014 FIRN conference, the 2015 Economic History Society meetings, and the 2016 EurHistock conference provided useful comments. We would like to thank the Department of Finance at Melbourne University for generous financial support to undertake this project. David Convery, Lisa Gardner, Victoria Holmes, Nathan Richards, and Pamela Schievenin provided excellent research assistance. This paper previously circulated under the title 'The Vicar, the Widow, or the Gentleman: Who is informed about IPO firms?'. Responsibility formistakes and omissions rests with the authors.

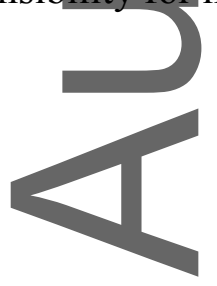

This is the author manuscript accepted for publication and has undergone full peer review but has not been through the copyediting, typesetting, pagination and proofreading process, which may lead to differences between this version and the Version of Record. Please cite this article as doi:

10.1111/ehr.12783.

This article is protected by copyright. All rights reserved. 


\section{An efficient market? Going public in London, 1891-1911}

There have been many claims that defects in the way British capital was invested led to insufficient domestic investment in the late nineteenth and early twentieth centuries. Hobson claimed that 'Foreign investment was ... sapping the life blood of British industry' and the Macmillan Report in 1931 concluded that 'our financial machinery is definitely weak in that it fails to give elear guidance to the investor when appeals are made to him on the behalf of home industry' 1 British banks would only loan to industry over short durations, in contrast to the closer links banks formed with industry in continental Europe. ${ }^{2}$ The criticism of British stock markets is that there were no suitable intermediaries, capable of bridging the information asymmetry between private firms and potential investors. 'Company promoters', who acted to sell shares in companies going public had, in general, a bad reputation. ${ }^{3}$ Kennedy points to the absence of banks, investment trusts, and insurance firms as leading to inefficiency. ${ }^{4}$ Edelstein claims that British savings were primarily directed overseas, with insufficient funds remaining for domestic industry. ${ }^{5}$

We analyse the British IPO market from 1891 to 1911 and examine the 339 firms that went public via the main 'Official Quotation' market. We find no evidence of bias by investors in the primary market. Investors did not demand a higher return to invest their money in firms in emerging industries. Nor did investors irrationally purchase shares in foreign IPOs that delivered lower returns. In fact, over the long-run, 'new-technology' firms (i.e. chemicals,

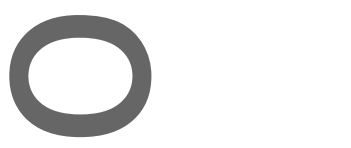

\footnotetext{
- We thank Oyvind Bohren, François Derrien, Espen Eckbo, Lorenzo Garlappi, Will Gornell, Bruce Grundy, Leslie Hannah, Alexander Ljungqvist, Oyvind Norli, John Turner, William Wilhelm and LiAnne Woo for helpful comments. Seminar participants at ANU, BI Norwegian Business School, Bond University, NHII Norwegian School of Economics, Oslo Business School, Queen's University of Belfast, Tilburg University, University of Bonn, University of British Columbia, University of Melbourne, University of Stavanger, University of Virginia, the 2014 FIRN conference, the 2015 Economic History Society meetings, and the 2016 EurHistock conference provided useful comments. We would like to thank the Department of Finance at Melbourne University for generous financial support to undertake this project. David Convery, Lisa Gardner, Victoria Holmes, Nathan Richards, and Pamela Schievenin provided excellent research assistance. This paper previously eirculated under the title 'The Vicar, the Widow, or the Gentleman: Who is informed about IPO firms?'. Responsibility for mistakes and omissions rests with the authors.

${ }^{1}$ Hobson, Export of Gapital.

${ }^{2}$ See Burhop, Chambers and Cheffins, 'Regulating IPOs'; Collins and Baker, Commercial banks, p. 63; Guinnane, 'Delegated monitors'; and Fohlin, 'Relationship banking'; idem, Mobilizing money.

${ }^{3}$ See Armstrong, 'Hooley and Bovril'.

${ }^{4}$ Kennedy, Industrial structure. See also Paish, 'New issue market'; Crafts, 'Victorian Britain'; Cottrell, Industrial finance; Pollard ,'Capital exports'; and O'Rourke and Williamson, Globalization and history.

${ }^{5}$ Edelstein, Overseas Investment.
} 
electricity and electro-technical, bicycles and cars) and foreign firms performed slightly better than other types of firms. ${ }^{6}$

A market is semi-strong efficient if abnormal profits cannot be made with publicly available information. ${ }^{7} \mathrm{We}$ find little evidence that abnormal profits could have been gained purely by using the information available in a firm's prospectus to buy IPO shares and sell them immediately once the firm was listed on the London stock exchange. A market is strong-form efficient if abnormal profits cannot be made with private information. We find some evidence of investors (who plausibly possessed some private information by virtue of their occupation or physical location) who had the ability to discern high-quality from low-quality firms. There is evidence of the private benefits of information in both 'new-tech' and 'old-tech' IPOs, as well as in both foreign and domestic IPOs. British IPOs needed to be underpriced, on average, in these major IPO groupings, in order to protect the less well-informed investors from being exploited. Investors who worked in the same industry as the firm going public, and investors who lived close to the firm, invested more heavily in high-quality firms. Local and industry-based knowledge are likely private to an individual, and hence the London market was not strong-form efficient, a finding in line with Fama and many others. ${ }^{8}$ The market was not just 'inefficient' for domestic, 'old-tech' firms, it was 'inefficient', in the sense of private information being valuable, across the board.

At the same time as British investors were, allegedly, sending too much of their capital overseas, they also supposedly had advantages to investing locally. In the late nineteenth and early twentieth centuries investors lived close to the firms in which they invested. ${ }^{9}$ Franks et al. as well as Campbell and Turner argue that investors benefited from informal trust mechanisms' the closer they were to a firm. ${ }^{10}$ Rutterford et al. assert that local bias by shareholders was a way to 'overcome informational asymmetries' and similar claims have been made by Michie and Lavington. ${ }^{11}$ We find some evidence of skill by local investors. Local investors were allotted more shares in IPOs that performed well over the first three years of their life relative to their allotment in IPOs that performed poorly. 
Recent work by Goetzmann and Ukhov and by Chabot and Kurz has shown that British investors were not irrationally sending their money overseas, but rather rationally obtaining higher risk-adjusted returns. ${ }^{12}$ Those studies examine the returns and covariances of listed securities, which naturally are heavily weighted towards old, established firms. However, most of the criticism of British capital markets has been levied against newly issued securities, which Goetzmann and Ukhov and Chabot and Kurz do not directly study. Criticism of the primary market comes from Kennedy, who states that 'the stock exchanges as a whole had a distressing trend to launch new issues, especially for firms in new industries, disastrously'. 13 Harrison takes a more nuanced view, but claims that 'formal company flotation inadequately served several of the [cycle, tyre, steel tubing and motor vehicle] firms'. ${ }^{14}$ DeLong also links the lack of certifying institutions (such as J. P. Morgan) in Britain to 'anaemic domestic investment, large overseas investments, and relative industrial decline'. ${ }^{15}$ In contrast Hannah argues that informal networks between company promoters and investors were sufficient to place securities. ${ }^{16}$

The Berlinmarket, in particular, has been described as friendly to innovative firms in this period. Lehmann-Hasemeyer and Streb find that roughly 70 of the 474 (14.8 per cent) Berlin IPOs between 1892 and 1913 mention patents in their prospectus. ${ }^{17}$ In our sample, 32 of the 339 firms (9.4 per cent) that went public in the U.K. mentioned patents. Although our figures are lower, they are not substantially so, and it is possible that we understate the amount of innovative capital raised in London. Innovative firms that went public in London may well have gravitated towards the second-tier, 'special settlement', market (e.g. Marconi's Wireless Telegraph in 1900) or firms may not have mentioned in their prospectus patents that they intended to exploit (e.g. Samuel Courtauld and Co. in 1904). ${ }^{18}$ We only study the 'official quotation' or main market. ${ }^{19}$ Roughly two-thirds of firms that went public in London over the 1900-1913 period used the 'special settlement' market. ${ }^{20}$ The London stock exchange did not seem to discriminate against 'new-tech' firms which applied for an official quotation. 'New-

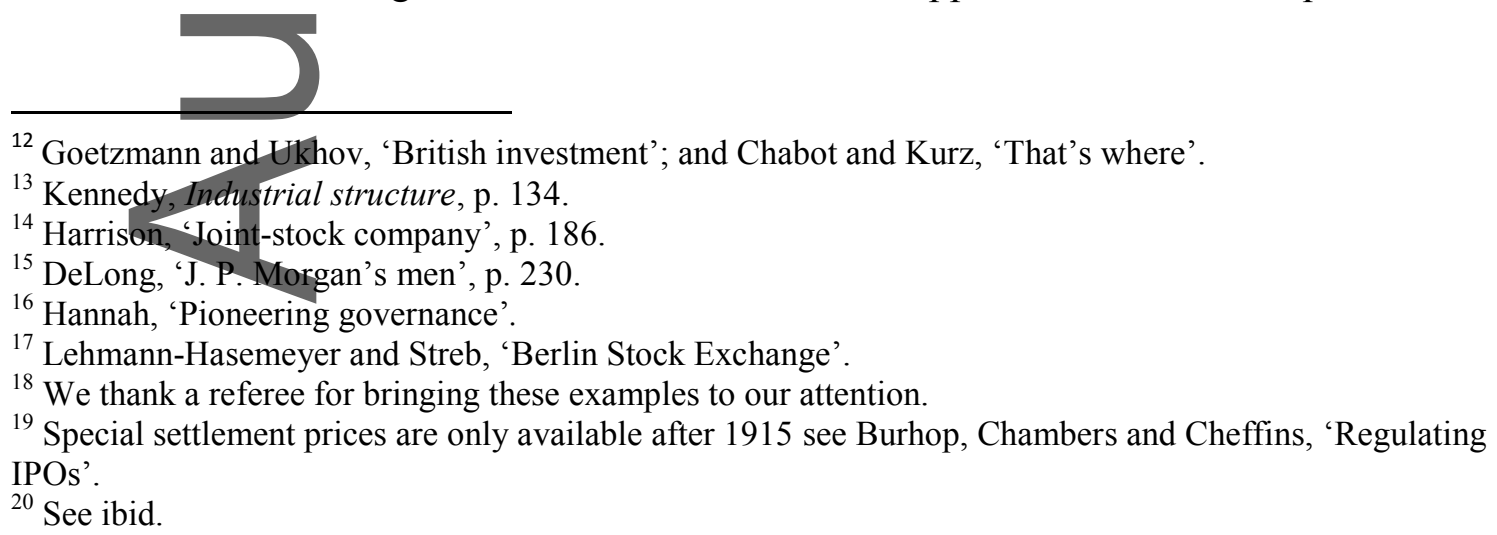


tech' firms that applied for a quotation had an 81 per cent success rate, virtually indistinguishable from the 84 per cent success rate of 'old-tech' firms.

We find few variables that are correlated with IPO underpricing, that is the percentage gain or loss made by investors from the time they subscribed for shares until the first day upon which those shares were quoted on London. This result mirrors Burhop's finding for German firms in this era ${ }^{21}$ However, there were clear warning signs about a firm's long-run performance. A firm with a political or a military director tended to do poorly over the three years after it was floated, as did furms that had used underwriters. Firms endogenously chose who to place on their board, and they had to make a conscious decision to engage an underwriter. Low-quality firms that (correctly) perceived they would have a problem in obtaining sufficient investor interest tended to add a politician or a colonel to their board to encourage naïve investors to participate, or perhaps hired an underwriter. ${ }^{22}$ Within the first three years of the firm's life the quality of the firm tended to become apparent to all, and low-quality firms' stock prices declined relative to high-quality firms. In other words, semi-strong efficiency did not appear to hold in the medium-run for British IPOs. Astute British investors did not appear to need investment banks to certify firm quality.

The late nineteenth and early twentieth centuries were a boom time for British equity markets. Ord established companies were taken public via IPOs as founding families drew down their personal holdings and offered shares to the wider public. ${ }^{23}$ The number of investors who personally owned shares is estimated to have risen from 250,000 to one million and there were over 5,000 members of the London stock exchange by $1905 .^{24}$ The nominal value of quoted securities almost doubled from 1893 to 1913, with the fastest growing components being banks, breweries, iron and coal works, electric lighting and power firms. It seems unintuitive that obviously vigorous markets in the United Kingdom would be inefficient, and indeed they were not.

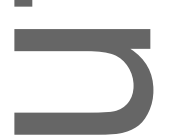

We collect data on every firm that offered ordinary shares to the public via a prospectus that was published in The Times, a London newspaper, and had those ordinary shares officially

\footnotetext{
${ }^{21}$ Burhop, 'Underpricing'.

${ }^{22}$ See Braggion and Moore, 'Economic benefits'.

${ }^{23}$ See Cheffins, 'Does law matter?'; Franks, Mayer, and Rossi, ‘Ownership'; and Hannah, 'Pioneering governance'.

${ }^{24}$ Michie, London Stock Exchange, pp. 72, 84.
} 
quoted in London within two years of the prospectus. ${ }^{25}$ We use the Stock Exchange Official Intelligence and the Stock Exchange Daily Official List for information on which firms were officially quoted. We find 339 IPO firms with an aggregate size of $£ 175.6$ million that went public on the London market over the period 1891 to 1911.

\section{Table 1 about here}

In Table 1-we compare the characteristics of IPO firms in traditional, 'old-tech' sectors versus firms in 'new-tech' industries. Underpricing is traditionally interpreted as an indicator of information asymmetry problems between the firm and investors. ${ }^{26} \mathrm{We}$ measure underpricing as the return of the firm from the day of the prospectus to the first listing day less the return from a weekly London market index over the closest overlapping period. We extend the weekly market index of Braggion and Moore. ${ }^{27}$ Although the IPO literature has followed Ritter in measuring raw returns, without an adjustment for market movements, this is inappropriate for the London market in this era given the long delays from prospectus to listing. ${ }^{28}$ In Ritter's sample '[f]or most of the offerings, the first recorded after-market bid price is on the date of the offering', whereas in our sample the average time from prospectus to first observed price is 207 days. ${ }^{29}$ Lehmann's study of the German IPO market in this era also adjusts for overall market movements. ${ }^{30}$

In line with most studies of IPOs we find skewness in underpricing whereby mean underpricing exceeds the median. ${ }^{31}$ 'Old-tech' firms had higher mean underpricing than that for 'new-tech' firms although there is no statistically significant difference. 'Old-tech' firms had lower median underpricing, 1.2 per cent versus 6.9 per cent, although again the difference is relatively small given the large standard deviation of underpricing. Statistically indistinguishable underpricing is the first piece of evidence that investors did not discriminate against' 'new-tech' firms.

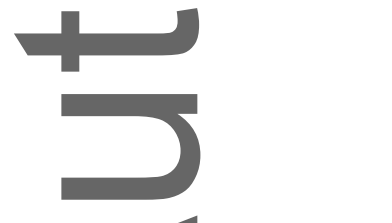

\footnotetext{
${ }^{25}$ The average time from prospectus to listing was six months.

${ }^{26}$ See, for example, Baron, 'Model of the demand', where investors are considered to be homogenous, and less informed, than the firm.

${ }^{27}$ Braggion and Moore, 'Dividend policies'.

${ }^{28}$ Ritter, 'Hot issue'.

${ }^{29}$ See ibid, p. 217.

${ }^{30}$ See Lehmann, 'Taking firms'. Our results are largely unchanged if we use unadjusted underpricing as market movements are virtually uncorrelated with IPO outcomes.

${ }^{31}$ See, for example, Chambers and Dimson, 'IPO underpricing'.
} 
'Old-tech' firms were more likely to be foreign firms (44 per cent) than were 'new-tech' firms (24 per cent). ${ }^{32}$ Both sets of firms offered, almost exactly, two-thirds of their shares to the public. This is mostly due to the London Stock Exchange's 'two-thirds rule'. ${ }^{33}$ We search The Times' The Money Market' column to locate all applications to the London Stock Exchange for an Official Quotation. We then read the companies' submissions to the Stock Exchange. ${ }^{34}$ In most applications the total number of shares applied for is reported. The mean 'old-tech' firm was almost one and a half times oversubscribed, compared to just 30 per cent oversubscription for 'new-tech' firms, although median differences are much lower.

For a subset of 136 firms, for which ownership records have been retained by The National Archives, we locate the list of shareholders, their names, addresses and self-reported occupations (that is, the firm's Form E, Summary of Capital and Shares or occasionally the IPO allotment list). 'Old-tech' firms' shareholders were far more likely to work in the same industry as the firm (20.2 per cent) than 'new-tech' shareholders (7.5 per cent). Both types of firms had around one-quarter of their shareholders located in the same 'area' as the firm itself. $^{35}$

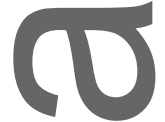

One-third of both types of firms used underwriters. Unsurprisingly, 'old-tech' firms were substantially older (21.1 versus 7.5 years) and reported a longer track record of profits (2.4 years versus 1.2 years) than 'new-tech' firms. 'Old-tech' firms were also larger, $£ 526,000$ versus $£ 455,000$, although this difference is not statistically significant. 'New-tech’ firms had fewer tangible assets, and were far more likely to mention a patent in their prospectus. Both types of firms frequently placed politicians and military officers on their boards, although there is no statistical difference in the frequency of such placements between 'new-tech' and 'old-tech' firms.

British firms that went public were highly likely to list on London. We find only 31 firms that offered ordinary shares in The Times and were listed on a provincial stock exchange within two years. We have been unable to locate comprehensive stock price lists for the provincial exchanges; therefore their IPOs are not in our sample.

\footnotetext{
${ }^{32}$ A firm is classified as foreign if most of its operations were located outside the United Kingdom.

${ }^{33}$ See Cheffins, Koustas, and Chambers, 'Ownership dispersion'; and Hannah and Foreman-Peck, 'Ownership dispersion'.

${ }^{34}$ Listing files are obtained from the Guildhall Library in London.

${ }^{35}$ An area is defined as the country, if outside Britain. Within Britain an area is either a city (e.g. Glasgow, Birmingham) for cities over 200,000 people or a county (e.g. Staffordshire). As London is so large, within London we define an area as the postal district (e.g. N, NW, W, EC).
} 
Burhop and Lehmann-Hassemeyer find that smaller, provincially-located German firms tended to list on provincial exchanges, which they speculate may be driven by an attempt from the firm to ameliorate information asymmetry between the firm and (local) investors. ${ }^{36}$ Campbell, Rogers and Turner show that British provincial exchanges had a moderate number of listings, relative to London, but many of the firms listed on provincial exchanges were in the old, established sectors of railways and banks, which had very few IPOs in the era we study. $^{37}$

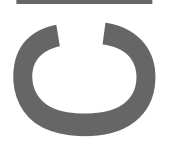

\section{Table 2 about here}

In Table 2 we split our IPO sample between domestic (198) and foreign (141) firms. We find some evidence of larger information asymmetry problems between investors and the firm in the foreign sector. The larger information asymmetry is reflected in higher mean underpricing for foreign firms, although median underpricing is lower for foreign firms. Long-run stock price performance, measured over the time from prospectus to three years after the stock market debut, is virtually identical at the mean, although the median foreign firm performs substantially worse.

Domestic firms are more likely to be 'new-tech' than are foreign firms. Unsurprisingly, given that these IPO firms were marketed to British investors, we find that domestic firms had higher rates of ownership by investors in the same geographical area as the firm. Foreign firms were more likely to use an underwriter, and were less likely to state in their prospectus that they were seeking an official quotation. Domestic firms tended to be older, larger, and reported a longer track-record of profits. Domestic companies also had more tangible assets than foreign firms, and were also more likely to mention patents in their prospectus. There were small differences in the rate at which firms used politicians or military officers on their boards.

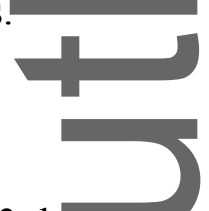

\section{Table 3 about here}

Table 3 doeuments the industrial composition of the IPOs in our sample. We use the classification that the stock exchange used in their Stock Exchange Daily Official List. Firms come from a wide range of industries. Commercial and Industrial (the most numerous category of the Official List) comprise almost half our sample, with the boom industry of

\footnotetext{
${ }^{36}$ Burhop and Lehmann-Hassemeyer, 'Berlin stock exchange'.

${ }^{37}$ G. Campbell, M. Rogers and J. Turner, 'The rise and decline of the UK's provincial stock markets, 18691929’, QUCEH Working Paper Series No. 2016-03 (2016).
} 
rubber plantations the next largest. Apart from these two categories the distribution of IPOs is widely spread across industries. ${ }^{38}$ Figure 1 shows the number of IPOs by year. There was a widespread boom in IPO activity in the late 1890s and a rubber boom around 1910.

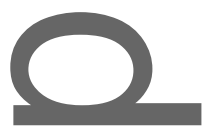

II

\section{Figure 1 about here}

In Table 4 we investigate the determinants of shareholder subscription rates. Firms that applied to the London Stock Exchange usually, but not always, reported the total number of shares applied for. As an example, Lovell and Christmas in their application of 3 September 1896 for an official quotation wrote to the stock exchange that 'According to Official Documents and Statutory Declarations, 166,832 Ordinary Shares ... were applied for by, and 26,667 Ordinary Shares ... were unconditionally allotted to the public'.

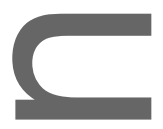

Table 4 about here

We find that there are virtually no firm characteristics that are robustly associated with obtaining more, or fewer, subscriptions from the public. A politician on the board is associated with lower subscription rates, and a lower likelihood of being fully subscribed. ${ }^{39}$ However, given that having a politician on the board is endogenously determined by the firm, it may well be that firms who would anyway have had low subscription rates chose to seat politicians on the board to somewhat alleviate the lack of public demand for their shares. Firms that used a more experienced bank to accept share applications tended to have lower subscription rates, but again the direction of causality is unclear.

Characteristics that, supposedly, deterred investors do not appear to have been important. Foreign firms and patenting firms are estimated to have received more subscriptions than their counterparts, although these estimates are statistically insignificant. 'New-tech' firms are associated with 26.5 per cent less investor demand, although the estimate on getting fully subscribed insignificant. In short, the claims of Harrison and Kennedy that the London market was unwellcoming to new industries finds little support. ${ }^{40}$

\section{III}

\footnotetext{
${ }^{38}$ The one railroad we classify as 'new-tech' is the Great Northern, Piccadilly and Brompton Railway, an underground, electrified railway, now the Piccadilly line of the London Tube.

${ }^{39}$ We estimate a linear probability model (see Angrist and Pischke, Mostly harmless, for a justification). The equivalent probit model yields similar results.

${ }^{40}$ See Harrison, 'Joint-Stock Company'; and Kennedy, Industrial structure.
} 
If foreign or 'new-tech' firms were discriminated against, perhaps because of more severe instances of information asymmetry between those firms and British investors, then investors would demand a higher return to apply for shares in those firms' IPOs. A higher return is equivalent to increased underpricing of the IPO.

\section{Table 5 about here}

In Table 5-we report regressions of IPO underpricing on firm characteristics as reported in their prospectus. We find few variables that are correlated with underpricing in this period (a result in line with that for Germany in this era by Burhop. ${ }^{41}$ There is little evidence that 'newtech' firms were considered riskier by investors, the coefficient on 'new-tech' is small and insignificant. Foreign firms were underpriced more, although the coefficient is only statistically significant once we condition on the application rate (column 2). Larger firms and underwritten firms seem to have faced reduced information asymmetry, as they were associated with lower underpricing.

Rock's seminal model of IPO underpricing argues some (informed) investors can tell a good (i.e. underpriced) IPO from a bad (overpriced) IPO based on private information. ${ }^{42}$ Therefore, an underpriced IPO will attract a lot of applications whereas an overpriced IPO will attract relatively few applications. Rock's model implies that observable characteristics are of no use in predieting underpricing, although the ex-post realization of investor demand will be positively correlated with underpricing, as we show in column 2.

The IPO market in Britain has been compared unfavourably with Germany. ${ }^{43}$ Burhop and Lehmann present results for late nineteenth and early twentieth century Germany which demonstrate mean underpricing of around 3 to 4 per cent. ${ }^{44}$ Such low underpricing would seem to indicate that German investors embraced IPO firms without demanding a high expected return. However, the German IPO process operated differently to that in the U.K. German firms would often first sell themselves to an underwriting syndicate, usually a group of large banks, and then the banks would then offer shares to the public. Burhop documents that in the first stage of the process the bank(s) would buy the shares from the issuing firm

\footnotetext{
${ }^{41}$ Burhop, 'Underpricing'.

${ }^{42}$ Rock, 'New issues'.

${ }^{43}$ See, for example, Gerschenkron, Economic backwardness; Lehmann, 'Taking firms'; and de Long, 'J. P. Morgan's men'.

${ }^{44}$ Burhop, 'Underpricing'; and Lehmann, 'Taking firms'.
} 
and then mark up the price by around 14.6 per cent when offered to the public. ${ }^{45}$ Therefore, the cost to a German firm in terms of 'money left on the table' is the sum of these two discounts, roughly 20 per cent if a firm went public via large German banks.

Calomiris, in a much smaller study, calculates that investors going public via German investment banks lost around 5 per cent of the money raised (roughly half in fees and half in the 'spread'). ${ }^{46}$ In contrast, private British firms would usually first incorporate as a 'syndicate', with the key individuals in the private firm and the syndicate the same. Then the syndicate would offer shares directly to the public via a prospectus. Firms that went public in the U.K. from 1891 to 1911 achieved mean underpricing of 12.8 per cent (median 1.8 per cent, calculated from Table 1). Chambers and Dimson document even lower underpricing, 3.8 per cent, from 1917 to $1945 .^{47}$ The situation in the U.S. is less understood, mainly due to a paucity of data, but the available evidence is that investment bank fees for common stock issues were around 20 per cent. ${ }^{48}$

Roughly two-thirds of U.K. IPOs were issued without the services of an underwriter. Chambers and Dimson state that 'until 1929 ... underwriting was conducted by an assortment of company promoters, syndicates, company directors, stockbrokers, and a new breed of industrial trust 49 Prospectuses in our sample often do not mention the name of the underwriter, but say something similar to Wigham and Richardson's IPO in 1899 which stated that 'the Vendors have entered into contracts with third parties with reference to the subscription of the capital'. Of the one-third of IPO firms that used an underwriter, and disclosed the underwriters' fees, the fees averaged 5.4 per cent. ${ }^{50}$ The cost, to the firm, of going public in the U.K. was the sum of the underpricing and the underwriting costs (if any). Therefore, the cost of going public in the U.K. was roughly equal to that in Germany. The lack of dedicated intermediaries, such as investment banks, did not appear to be a major impediment to the efficient functioning of Britain's capital markets.

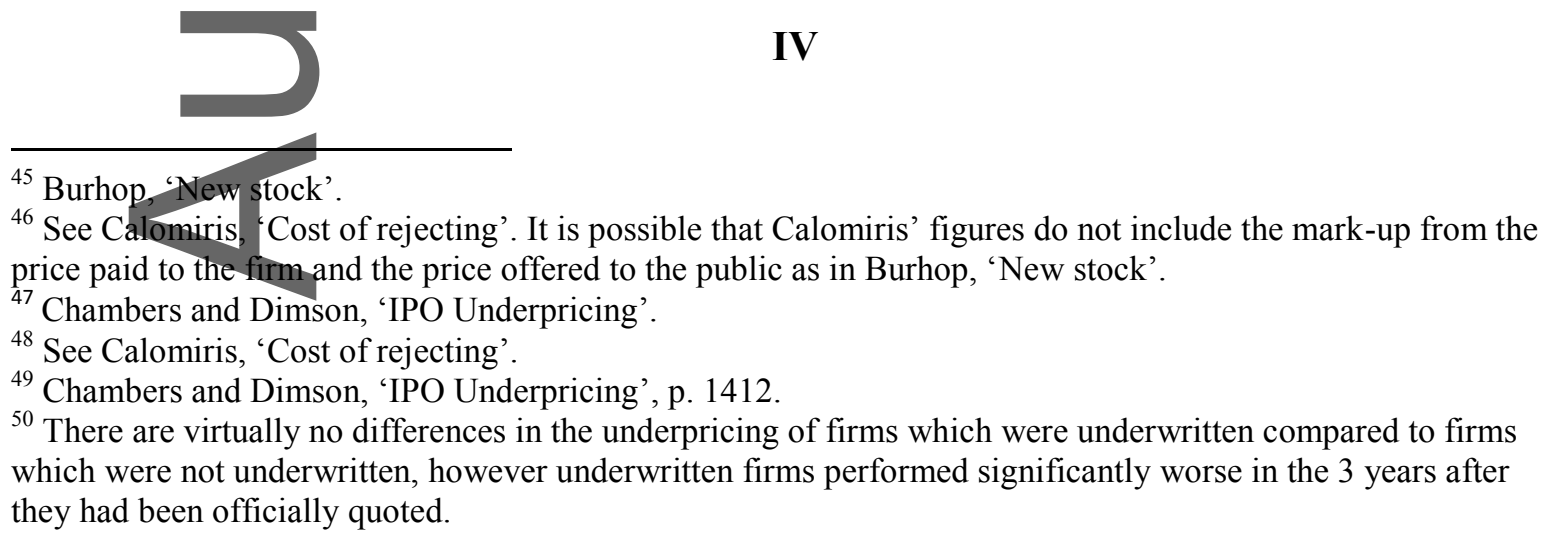


We now examine the relation between firm characteristics and long-run performance. In common with modern studies of IPOs, such as Ritter and Carter, Dark and Singh we document poor long-run performance relative to the overall market in Tables 1 and $2 .{ }^{51}$ Those authors argue that long-run performance is important to study since it may shed light on possible 'fads' and overoptimism. British capital markets experienced several fads in the era we study. There was a wave of brewery flotations in the 1890s, as well as a rush in cycles in the mid-1890s, and a boom in tea, coffee, and rubber shares in the late $1900 \mathrm{~s}^{52}$ In addition, long-run performance sheds light on the informational efficiency of the primary issues market. We follow Ritter and Carter, Dark and Singh and examine the return to IPO shares from the date of the prospectus until three years after the firm first appeared on the London exchange. ${ }^{5}$

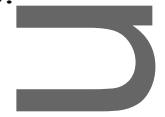

\section{Table 6 about here}

We find clear associations between certain firm characteristics and long-run performance. In Table 6 we regress the firm's medium-run performance (namely the firm's three-year return less the return on a London market index) on firm characteristics as reported in the prospectus. We find that foreign and 'new-tech' firms obtained superior long-run performance, although these effects are usually statistically insignificant.

The placement of a politician or, even worse, a military officer on the board is associated with poor long-run performance. A military officer is associated with a three-year IPO return 53 percentage points to 74 percentage points worse than an identical IPO without an officer. Causality may have flowed from a 'low quality' firm to the use of 'ornamental' directors, rather than in the other direction. Low-quality firms may have been struggling to attract sufficient investor attention pre-IPO. In an attempt to obtain sufficient applications for shares these firms placed politicians and military directors on their boards. Braggion and Moore argue that a primary motive in placing a titled director on a board was to market the company to investors. ${ }^{54}$ These low-quality firms received fewer subscriptions anyway (despite the use of politicians and officers) as we show in Table 4, and as information was slowly revealed over the early years of these firm's life the stock price declined. These results support the

\footnotetext{
${ }^{51}$ Ritter, 'Long-run performance'; and Carter, Dark and Singh, 'Underwriter reputation'.

${ }^{52}$ See Acheson, Coyle and Turner, 'Happy hour'; and W. Quinn, 'Squeezing the bears: cornering risk and limits on arbitrage during the "British Bicycle Mania”, 1896-1898', Working Paper (Queen's University Belfast).

${ }^{53}$ Ritter, 'Long-run performance'; and Carter, Dark and Singh, 'Underwriter reputation'.

${ }^{54}$ Braggion and Moore, 'Economic benefits'.
} 
views of Campbell and Turner and Grossman and Imai that many British directors were not functionally involved in running the firm on whose boards they sat. ${ }^{55}$

Firms that-used an underwriter performed poorly, with a three-year return roughly 40 percentage points worse than similar, non-underwritten, firms. A likely explanation is that low-quality firms were forced to use an underwriter in the IPO process to ensure sufficient shares were placed. Firms which issued more shares to the public (and consequently company vendors retained fewer) performed worse than others.

In line with the results of Burhop, Chambers, and Cheffins we find that larger and older firms performed better, post-IPO, than smaller and younger firms. ${ }^{56}$ In contrast to Burhop et al.'s results we find no evidence that disclosure of a longer track-record of profits was associated with better long-run performance.

Tests of long-run returns need to be more carefully interpreted than tests of short-run returns. Variables that appear to be correlated with returns may simply indicate the presence of an omitted risk factor. ${ }^{57}$ Firms which obtained higher returns (large firms, older firms, nonunderwritten firms, and those without high profile directors) may have been riskier firms. As such, the higher returns may have been compensation for risk. Nonetheless, we find no support for the idea that 'new-tech' firms performed worse than established firms, or that foreign firms' returns tended to be lower. Both foreign and 'new-tech' firms appear to have been treated virtually identically to other types of firms.

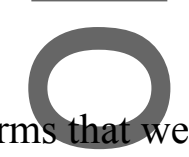

\section{V}

Many firms that went public in London have left records of who were allotted the shares in the IPO. British firms registered under the 1862 Companies Act were required to file an annual Form E, which report the number of shares held, the address and occupation of the owner, and the number of shares sold during the previous year. Some Form Es also report the names of both the buyer and seller of shares during the past year. A random selection of Form Es are retained in the National Archives at Kew. ${ }^{58}$ We supplement these Form Es with companies self-reported allotment lists. Allotment lists can sometimes be found at Companies House, Cardiff, and sometimes as part of the application for listing file held by

\footnotetext{
${ }^{55}$ See Campbell and Turner, 'Legal protection'; and Grossman and Imai 'Taking the lord's name'.

${ }^{56}$ Burhop, Chambers and Cheffins, 'Regulating IPOs'.

${ }^{57}$ See Lyon, Barber, and Tsai, 'Improved methods'.

${ }^{58}$ See Braggion and Moore 'How insiders traded'.
} 
the Guildhall Library. We use the Form E (end-of-period) number of shares held, add back sales, and subtract purchases (if possible), to arrive at the number of shares an individual would have been allotted by the company as part of the IPO.

We characterize the information asymmetry that likely existed between the public and the firm with two measures: did the shareholder work in the same industry as the firm (ie.

Related Occupation equals one) and did the shareholder live nearby one of the firm's areas of operations (ie. Related Location equals one). Shareholders who lived and/or worked 'close' to the firm may have had private information about the firm. Such investors may have been able to distinguish high-quality from low-quality IPOs for 'close' firms.

We use the self-reported occupation of a shareholder that appears in the firm's allotment or shareholder list: 12 per cent of the shareholders did not have their occupation recorded in the Form E (these are dropped for subsequent analysis), 26 per cent have generic occupations (e.g., gentleman, esquire, married woman, widow), and 62 per cent have a specific occupation recorded (e.g., clergyman, water works superintendent, tea merchant). We classify a shareholder's occupation at the sub-order level of the Census of England and Wales 1911. ${ }^{59}$ Acheson, Coyle and Turner show that roughly 40 per cent of capital raised by late nineteenth century British firms came from whom they term 'rentiers' (namely gentlemen, esquires and others without specified occupations). ${ }^{60}$ Businessmen supplied roughly 20 per cent, with the middle classes and women supplying the remainder. To define a related occupation for an IPO we classify the activities of the firm using the census sub-order categories. For example, Magadi Soda Ltd. operated a soda mine and railway in Kenya (then British East Africa) under a 99-year lease from the Colonial Office (a branch of the British government). The firm's prospectus mentions that its product is used in 'numerous industries, as, for instance, by Soap, Glass, and Paper Makers, and by Textile Manufacturers for Printing, Bleaching, and Dyeing, Consequently, we define occupation codes 1.1 (which includes civil service officers and clerks), 3.6 (eivil and mining engineers and surveyors), 6.1 (railway officials and clerks), 15.1 (dyeing manufacturers), and 18.6 (textile bleachers, printers and dyers) as related. The classification of the firm's activities into occupations/industries is necessarily subjective, and the classifications are available upon request. In general, we have erred on the side of

\footnotetext{
${ }^{59}$ See http://www.familyheritagesearch.co.uk/2013/02/1911-census-codes/

${ }^{60}$ See Acheson, Coyle and Turner, 'Happy hour'.
} 
classifying too many investors as related. ${ }^{61}$ Any errors will make finding results more difficult. We define an investor as geographically related, for that IPO, if he/she provides an address that is in the same geographical area as any one of the firm's location(s).

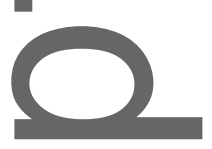

\section{Table 7 about here}

In Table 7 we regress the number of shares allotted to an individual on that individual's characteristies (were they in a related occupation or did they live in a related location to the firm), and whether the IPO was underpriced (did the investor make money by investing in that IPO). We-split the sample between 'old-tech' and 'new-tech' firms.

We find that investors in the same geographical area as an 'old-tech' firm tended to receive larger share-allocations than investors elsewhere. This is evidence of the well-known 'home bias' in investment. Sharing the same location as an 'old-tech' firm was related to receiving an extra 16.4 per cent shares in an IPO, no matter how well the IPO performed. We then interact occupation and location with a dummy variable Underpriced which equals one if the return on the shares from prospectus to listing outperformed the market and zero otherwise. 'Old-tech' investors who worked in the same occupation as the firm received, on average, 15.2 per cent more shares in an IPO if it performed well (Underpriced equals one) than if it performed badly. In other words, working in the same industry as the firm seemed to offer investors an informational advantage - when considering IPOs in their own industry. Those investors invested more in well-performing IPOs and shied away from poorly-performing IPOs. We find no such informational advantage from being located in the same geographical area.

The results for 'new-tech' firms are similar. Sharing the same location as the firm was related to receiving 6.1 per cent fewer shares in an IPO. Investors who worked in a 'new-tech' industry were allotted substantially fewer shares in 'new-tech' IPOs, except for those IPOs that performed well. That is, investors who worked in an emergent industry could discriminate between good 'new-tech' firms and bad 'new-tech' firms which wished to raise money. Our results suggest that there were skilled investors, able and willing to provide capital to innovative firms if those firms were good enough.

\section{Table 8 about here}

\footnotetext{
${ }^{61}$ Investors who style themselves 'gentlemen', 'esquires', 'married', and 'widows' are not allocated to a census occupation, since there is not enough information to reliably place them in one of the occupational categories. 
We now examine the allotment of shares between domestic and foreign firms in Table 8. In general, the results here are less clear-cut than the split between 'old-tech' and 'new-tech' firms. For both U.K. and foreign firms, investors who lived in the same location as the firm were allotted more shares. For U.K. IPOs there is evidence that investors in a related occupation received more shares (11.6 per cent) in underpriced IPOs than investors in other occupations. However, there is no evidence that local investors could discriminate between well-performing and poorly-performing companies. In fact foreign investors received fewer shares in foreign IPOs that performed well.

In both Tables 7 and 8 we use firm, occupation and location fixed effects. The use of fixed effects is critical to our results. Investors in some occupations are likely to be wealthier than others, hence to receive larger allotments in all IPOs, occupation fixed effects will control for this. In addition, we allow for differences in wealth by geographic region - which is important since London residents were, on average, richer than residents of rural Irish counties. Location fixed effects controls for these geographic differences. Finally, we use firm (that is IPO) fixed effects. Some IPOs issued more shares and/or received more total applications than others. Including firm fixed effects controls for differences in the availability of shares for investors to purchase. ${ }^{62}$

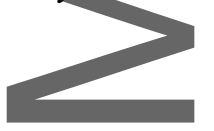

\section{Tables 9 and 10 about here}

In Tables 9 and 10 we repeat the earlier analysis, except that we replace IPO underpricing (from prospectus to the first day of trade on the stock exchange) with IPO long-run performance (from prospectus to 3 years after the first day of trade). Analyzing long-run performance allows for the possibility that the quality of some firms may take time to become evident to all, even after it has first listed on the London stock exchange. A poor-quality firm may be indistinguishable from a high-quality firm in the initial months from when it issued a prospectus until it was first listed on the stock exchange. However, over time increased investor scrutiny of publicly listed firms will reveal which firms are 'lemons' and which are sound.

In Table 9 we show a home bias for 'old-tech' firms. Investors in the local area of the firm received 10.2 per cent more shares (of overpriced firms) than investors from further away. In

\footnotetext{
${ }^{62}$ We also use Occupation * Underpriced fixed effects and Location * Underpriced fixed effects. This is important because investors in some occupations (or locations) may simply be 'smart' or 'well-educated'. Including these interaction fixed effects checks for an effect of being in a related occupation or location on top of intelligence or education differences. We get broadly consistent results without the interaction fixed effects.
} 
contrast, local investors tended to avoid overpriced 'new-tech' firms. Local investors received 35.9 per cent fewer shares in IPO firms that would go on to register a negative market-adjusted return over the first 3 years. Investors in a related occupation were allotted 12.6 per cent more shares for 'old-tech' firms that performed well. For 'new-tech' firms, location was vital. Local investors were allotted 74.6 per cent more shares in well-performing 'new-teeh' IPOs than poorly-performing 'new-tech' IPOs. Poorly thought through or poorly managed firms in emergent industries were avoided by local investors.

In Table 10 we split the firms into domestic and foreign. We find some evidence of investor ability. Investors in a related location received 14.8 per cent more shares in U.K. IPOs that achieved a positive 3-year return than those IPOs that registered a negative 3-year return.

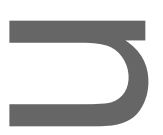

We study London initial public offerings from 1891 until 1911, a total of 339 firms that issued ordinary shares to the public for the first time. We find few differences in how investors treated old-tech' and 'new-tech' firms, both types of firms required modest price discounts (underpricing) to entice investors to apply for their shares. Similarly, we find little difference-in investor treatment of domestic and foreign firms.

There is circumstantial evidence that companies seeking a public listing employed various tactics to obtain sufficient applications for the company to proceed. Firms that placed politicians or military officers on their boards tended to do worse over the subsequent three years than firms without such directors. In addition, those firms tended to have lower levels of subscriptions. It is possible that ornamental directors were placed on the boards of struggling companies to (just) obtain enough subscriptions, and over the medium term those firms performed badly. In a similar fashion, firms that were underwritten or firms which had less share retention by insiders tended to do worse. Older and larger firms were those that did best in the-early years of a firm's life as a publicly quoted company.

There were investors that could reliably pierce the veil of information asymmetry between the public and the firm seeking an initial quotation on London. Investors who worked in the same industry as the firm, and investors who lived nearby the firms' operations tended to receive larger allotments of the companies' shares, in particular those companies that went on to perform well. This is strong evidence of an efficient primary market for British equities. 
There is no evidence that investors, or the London Stock Exchange listing committee, shunned emergent technology firms, or avoided domestic firms in favour of foreign firms.

\section{Footnote references}

Acheson, G., Coyle, C. and Turner, J., 'Happy hour followed by hangover: financing the UK brewery industry, 1880-1913', Business History, 58 (2016), pp. 725-51.

Angrist, J. and Pischke, J.-S., Mostly harmless econometrics (Princeton, 2009).

Armstrong, J., 'Hooley and the Bovril Company', Business History, 28 (1986), pp. 18-34.

Baron, D., A model of the demand for investment banking advising and distribution services for new issues', The Journal of Finance, 37 (1982), pp. 955-76.

Braggion, F. and Moore, L., 'Dividend policies in an unregulated market: the London Stock Exchange, 1895-1905', Review of Financial Studies, 24 (2011), pp. 2935-73.

Braggion, F. and Moore, L., 'The economic benefits of political connections in late Victorian Britain', Journal of Economic History, 73 (2013), pp. 142-76.

Braggion, F. and Moore, L., 'How insiders traded before rules', Business History, 55 (2013), pp. 565-84.

Burhop, C., The underpricing of initial public offerings at the Berlin Stock Exchange, 187096", German Economic Review, 12 (2011), pp. 11-32.

Burhop, C., 'New stock issues in Germany, 1882-1892: a comment to Professor Fohlin', Jouknal of Economic History, 73 (2013), pp. 531-6.

Burhop, C. and Lehmann-Hasemeyer, S., 'The Berlin stock exchange and the geography of German stock markets in 1913', European Review of Economic History, 20 (2016), pp. 429-51.

Burhop, C., Chambers, D. and Cheffins, D., 'Regulating IPOs: evidence from going public in London, 1900-1913', Explorations in Economic History, 51 (2014), pp. 60-76.

Calomiris, C., 'The cost of rejecting universal banking. American finance in the German mirror', in N. Lamoreaux and D. Raff, eds., Coordination and information: historical perspectives on the organization of enterprise (Chicago, 1995), pp. 257-321.

Campbeil, G. and Turner, J., 'Substitutes for legal protection: corporate governance and dividends in Victorian Britain', Economic History Review, 64 (2011), pp. 571-97.

Campbell, G., Rogers, M. and Turner, J., 'The rise and decline of the UK's provincial stock markets, 1869-1929', QUCEH Working Paper Series No. 2016-03 (2016). 
Carter, R., Dark, F. and Singh, A., 'Underwriter reputation, initial returns, and the long-run performance of IPO stocks', Journal of Finance, 53 (1998), pp. 285-311.

Chambers, D. and Dimson, E., 'IPO underpricing over the very long run', Journal of Finance, 64 (2009), pp. 1407-43.

Chabot, B- and Kurz, C., 'That's where the money was: foreign bias and English investment abroad, 1866-1907', Economic Journal, 120 (2010), pp. 1056-79.

Cheffins, B., 'Does law matter? The separation of ownership and control in the United Kingdom, Journal of Legal Studies, 30 (2001), pp. 459-84.

Cheffins, B., Koustas, D. and Chambers, D., 'Ownership dispersion and the London Stock Exchange's 'two-thirds rule': an empirical test', Business History, 55 (2013), pp. $667-90$.

Collins, M. and Baker, M., Commercial banks and industrial finance in England and Wales, 1860-1913 (Oxford, 2003).

Cottrell, $\mathrm{P}$, Industrial finance 1830-1914: the finance and organization of English manufacturing industry (1980).

Crafts, N., 'Victorian Britain did fail', Economic History Review, 2nd ser., XXXII (1979), pp. $533-7$

De Long, J. B., ‘Did J. P. Morgan's men add value?', in P. Temin, ed., Inside the business enterprise: historical perspectives on the use of information (Chicago, 1991), pp. $205-50$.

Edelstein, M., Overseas investment in the age of high imperialism: the United Kingdom, 1850-1914 (New York, 1982).

Fama, E., 'Efficient capital markets: a review of theory and empirical work', Journal of Finance, 25 (1970), pp. 383-417.

Fohlin, C., 'Relationship banking, liquidity, and investment in the German industrialization', Journal of Finance, 53 (1998), pp. 1737-58.

Fohlin, C.,Mobilizing money: how the world's richest nations financed industrial growth (Cambridge, 2012).

Franks, J., Mayer, C. and Rossi, S., 'Ownership: evolution and regulation', Review of Financial Studies, 22 (2009), pp. 4009-56.

Gerschenkron, A., Economic backwardness in historical perspective: a book of essays (Cambridge, MA, 1962). 
Goetzmann, W. and Ukhov, A., 'British investment overseas 1870-1913: a modern portfolio theory approach', Review of Finance, 10 (2006), pp. 261-300.

Grossman, R. and Imai, M., 'Taking the lord's name in vain: the impact of connected directors on 19th century British banks', Explorations in Economic History, 59 (2016), pp. 75-93.

Guinnane,T., 'Delegated monitors, large and small: Germany's banking system, 1800-1914', Journal of Economic Literature, 40 (2002), pp. 73-124.

Hannah, L., 'Pioneering modern corporate governance: a view from London in 1900', Enterprise and Society, 8 (2007), pp. 642-86.

Hannah, L. and Foreman-Peck, J., 'Ownership dispersion and listing rules in companies large and small: a reply', Business History, 56 (2014), pp. 509-16.

Harrison, A. E., Joint-stock company flotation in the cycle, motor-vehicle and related industries, 1882-1914', Business History, 23 (1981), pp. 165-90.

Hobson, C. K. The export of capital (1914).

Kennedy, W., Industrial structure, capital markets and the origins of British economic decline (Cambridge, 1987).

Lavington, F., The English capital market (1921).

Lehmann, S., Taking firms to the stock market: IPOs and the importance of large banks in imperial Germany, 1896-1913', Economic History Review, 67, (2014), pp. 92-122.

Lehmann-Hasemeyer, S. and Streb, J., 'The Berlin Stock Exchange in Imperial Germany: a market for new technology?', American Economic Review, 106 (2016), pp. 3558-76.

Lyon, J., Barber, B. and Tsai, C.-L., 'Improved methods for tests of long-run abnormal stock returns', Journal of Finance, 54 (1999), pp. 165-201.

Michie, R., The London Stock Exchange: a history (Oxford, 1999).

O'Rourke, K. and Williamson, J., Globalization and history: the evolution of a nineteenthcentury Atlantic economy (Cambridge, MA, 1999).

Paish, F. W., 'The London new issue market', Economica, 18 (1951), pp. 1-17.

Pollard, S, 'Capital exports, 1870-1914. Harmful or beneficial?', Economic History Review, 2nd ser., XXXVIII (1985), pp. 489-514.

Quinn, W. 'Squeezing the bears: cornering risk and limits on arbitrage during the "British Bicycle Mania”, 1896-1898', Working Paper (Queen's University Belfast).

Ritter, J., 'The "hot issue” market of 1980', Journal of Business, 57 (1984), pp. 215-40. 
Ritter, J., 'The long-run performance of Initial Public Offerings', Journal of Finance, 46 (1991), pp. 3-27.

Rock, K., 'Why new issues are underpriced', Journal of Financial Economics, 15 (1986), pp. $187-212$.

Rutterford, J., Sotiropoulos, D. and van Lieshout, C., 'Individual investors and local bias in the UK, 1870-1935', Economic History Review, 70 (2017), pp. 1-30.

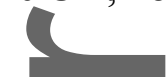

Figure 1: Number of IPOs per year

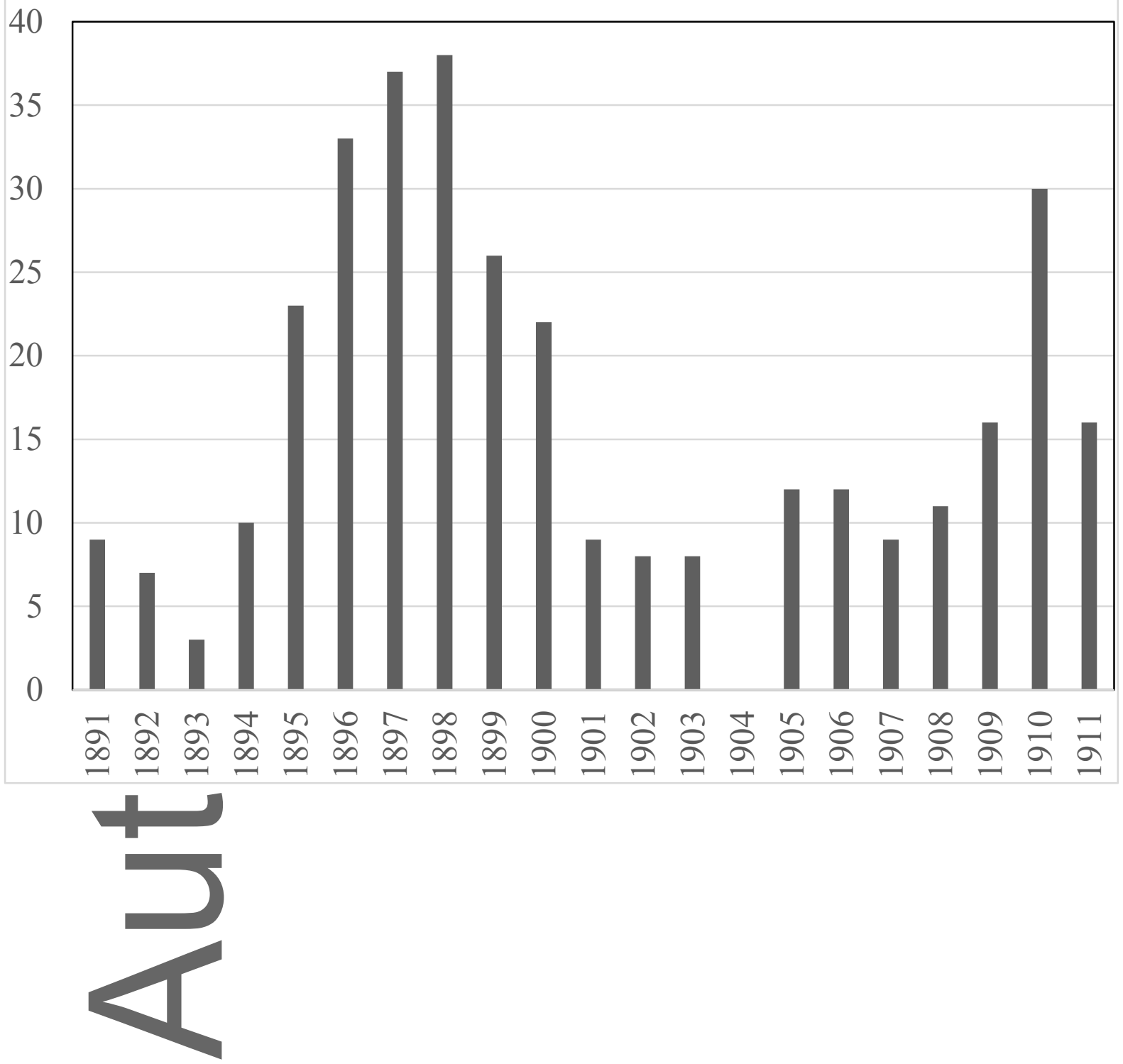


Table 1. IPO Summary Statistics (Old-Tech vs. New-Tech)

Underpricing is an excess return, return from offer price to the 1st day's price, less the market return over the same period. 3-year return is also an excess return, from the prospectus to 3 years after listing, over the market return. Foreign Firm equals one if the firm mainly operated outside the United Kingdom. Underwritten equals one if an arm's-length underwriter was used. Official quotation sought equals one if the prospectus states a quotation will be sought on London. Auditor / Lead Bank IPOs is the number of IPOs already handled by the auditor/bank on the prospectus. Track Record is the number of years of profits in the prospectus. Firm Size is the book value of equity plus the book value of debt. Tangibles is the yalue of tangible assets given in the prospectus. Any Tangibles equals one if there is a non-zero value of tangible assets. Patenting Firm equals one if there are patents mentioned th the prospectus. Politician/Military on Board equals one if there is at least one M.P. or Lord or director with a military title on the board.

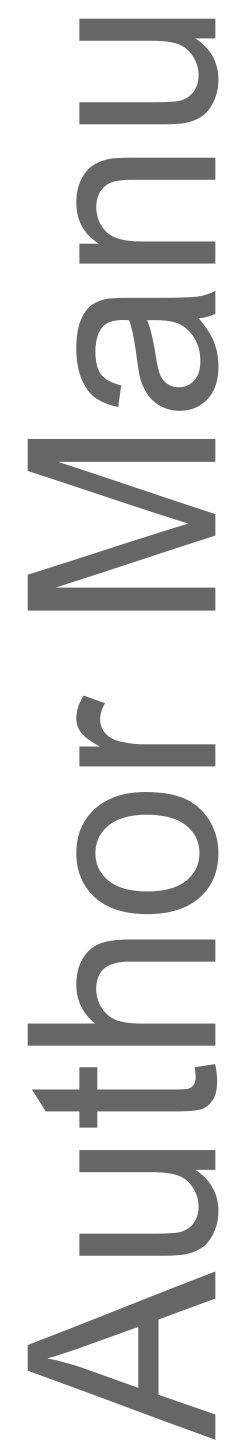




\begin{tabular}{|c|c|c|c|c|c|c|c|c|c|}
\hline & \multicolumn{4}{|c|}{ Old-Tech Firms } & \multicolumn{4}{|c|}{ New-Tech Firms } & \multirow{2}{*}{$\begin{array}{l}\text { p-value of } \\
\text { mean diffs }\end{array}$} \\
\hline & $\mathrm{N}$ & Mean & Median & Std. Dev & $\mathrm{N}$ & Mean & Median & Std. Dev & \\
\hline Underpricing (\%) & 301 & 13.1 & 1.2 & 63.0 & 38 & 10.5 & 6.9 & 25.7 & 0.63 \\
\hline 3-year return (\%) & 301 & -3.3 & -30.3 & 165.5 & 38 & -20.1 & -21.4 & 77.8 & 0.29 \\
\hline Foreign Firm & 301 & 0.44 & 0.00 & 0.50 & 38 & 0.24 & 0.00 & 0.43 & $0.01 * *$ \\
\hline$\%$ shares sold to public & 301 & 70.9 & 66.7 & 22.9 & 38 & 69.4 & 66.8 & 27.1 & 0.75 \\
\hline Share Applications (\% of Offered) & 243 & 244.8 & 135.9 & 282.0 & 33 & 132.1 & 116.6 & 69.9 & $0 * * *$ \\
\hline Ownership (\%) related occupation & 122 & 20.22 & 17.26 & 16.94 & 14 & 7.52 & 3.17 & 10.55 & $0 * * *$ \\
\hline Ownership (\%) related location & 122 & 22.72 & 15.17 & 23.28 & 14 & 25.40 & 23.79 & 24.37 & 0.73 \\
\hline Underwritten & 299 & 0.33 & 0.00 & 0.47 & 37 & 0.32 & 0.00 & 0.47 & 0.9 \\
\hline Official Quotation Sought & 299 & 0.89 & 1.00 & 0.32 & 37 & 0.78 & 1.00 & 0.42 & 0.16 \\
\hline Auditor IPOs (\#) & 301 & 14.3 & 7.0 & 16.6 & 38 & 8.1 & 2.5 & 15.0 & $0.02 * *$ \\
\hline Lead Bank IPOs (\#) & 301 & 24.8 & 20.0 & 19.0 & 38 & 33.5 & 38.0 & 19.7 & $0.01 * *$ \\
\hline Track Record (Years) & 301 & 2.40 & 1.00 & 3.11 & 38 & 1.24 & 0.00 & 2.14 & $0 * * *$ \\
\hline Firm Age (Years) & 300 & 21.1 & 5.0 & 32.8 & 38 & 7.5 & 3.5 & 11.9 & $0 * * *$ \\
\hline Firm Size $(£ ’ 000)$ & 301 & 525.9 & 280.0 & 973.9 & 38 & 455.1 & 275.0 & 622.7 & 0.54 \\
\hline Tangibles / Firm Size & 301 & 0.36 & 0.00 & 0.64 & 38 & 0.14 & 0.00 & 0.29 & $0 * * *$ \\
\hline Any Tangibles & 301 & 0.47 & 0.00 & 0.50 & 38 & 0.26 & 0.00 & 0.45 & $0.01 * *$ \\
\hline Patenting Firm & 301 & 0.07 & 0.00 & 0.25 & 38 & 0.32 & 0.00 & 0.47 & $0 * * *$ \\
\hline Politician on Board & 301 & 0.30 & 0.00 & 0.46 & 38 & 0.37 & 0.00 & 0.49 & 0.41 \\
\hline Military on Board & 301 & 0.12 & 0.00 & 0.32 & 38 & 0.24 & 0.00 & 0.43 & 0.1 \\
\hline
\end{tabular}

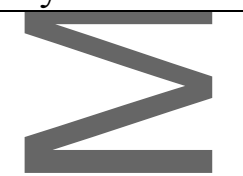

This is the muscript accepted for publication and has undergone full peer review but has not been through the copyediting, typesetting, pagination and proofrea nrocess, which may lead to differences between this version and the Version of Record. Please cite this article as doi: $10.1111 /$ ehr.12783.

This article coprod by copyright. All rights reserved. 
Table 2. IPO Summary Statistics (Domestic vs. Foreign)

Underpricing is an excess return, return from offer price to the 1st day's price, less the market return over the same period. 3-year return is also an excess return, from the prospectus to 3 years after listing, over the market return. Foreign Firm equals one if the firm mainly operated outside the United Kingdom. Underwritten equals one if an arm's-length underwriter was used. Official quotation sought equals one if the prospectus states a quotation will be sought on London. Auditor / Lead Bank IPOs is the number of IPOs already handled by the auditor/bank on the prospectus. Track Record is the number of years of profits in the prospectus. Firm Size is the book value of equity plus the book value of debt. Tangibles is the value of tangible assets given in the prospectus. Any Tangibles equals one if there is a non-zero value of tangible assets.

Patenting Firm equals one if there are patents mentioned in the prospectus. Politician/Military on Board equals one if there is at least one M.P. or Lord or director with a military title on the board.

\begin{tabular}{|c|c|c|c|c|c|c|c|c|c|}
\hline & \multicolumn{4}{|c|}{ Domestic Firms } & \multicolumn{4}{|c|}{ Foreign Firms } & \multirow{2}{*}{$\begin{array}{l}\text { p-value of } \\
\text { mean diffs }\end{array}$} \\
\hline & $\mathrm{N}$ & Mean & Median & Std. Dev & $\mathrm{N}$ & Mean & Median & Std. Dev & \\
\hline Underpricing (\%) & 198 & 7.5 & 3.2 & 28.6 & 141 & 20.3 & -0.9 & 86.2 & $0.09 *$ \\
\hline 3 -year return $(\%)$ & 198 & -5.3 & -8.5 & 95.8 & 141 & -5.0 & -47.8 & 217.8 & 0.99 \\
\hline New-Tech & 198 & 0.15 & 0.00 & 0.35 & 141 & 0.06 & 0.00 & 0.25 & $0.01 * *$ \\
\hline$\%$ shares sold to public & 198 & 68.3 & 66.7 & 22.5 & 141 & 74.1 & 71.4 & 24.3 & $0.03 * *$ \\
\hline Share Applications ( $\%$ of Offered) & 162 & 246.2 & 138.2 & 295.0 & 114 & 210.3 & 125.4 & 224.2 & 0.25 \\
\hline Ownership (\%) related occupation & 75 & 19.26 & 16.67 & 15.70 & 61 & 18.50 & 17.19 & 18.21 & 0.8 \\
\hline Ownership (\%) related location & 75 & 32.07 & 29.48 & 22.59 & 61 & 11.76 & 1.88 & 18.88 & $0 * * *$ \\
\hline Underwritten & 198 & 0.27 & 0.00 & 0.44 & 138 & 0.43 & 0.00 & 0.50 & $0 * * *$ \\
\hline Official Quotation Sought & 198 & 0.92 & 1.00 & 0.27 & 138 & 0.80 & 1.00 & 0.40 & $0 * * *$ \\
\hline Auditor IPOs (\#) & 198 & 13.2 & 6.0 & 15.9 & 141 & 14.2 & 6.0 & 17.5 & 0.58 \\
\hline Lead Bank IPOs (\#) & 198 & 27.4 & 23.0 & 18.9 & 141 & 23.4 & 17.0 & 19.4 & $0.07 *$ \\
\hline Track Record (Years) & 198 & 3.16 & 3.00 & 3.19 & 141 & 1.02 & 0.00 & 2.29 & $0 * * *$ \\
\hline Firm Age (Years) & 197 & 29.9 & 18.0 & 36.7 & 141 & 5.2 & 0.0 & 11.7 & $0 * * *$ \\
\hline Firm Size $(£ ’ 000)$ & 198 & 593.3 & 315.0 & 1163.3 & 141 & 412.1 & 225.0 & 461.0 & $0.05^{* *}$ \\
\hline Tangibles / Firm Size & 198 & 0.37 & 0.24 & 0.44 & 141 & 0.29 & 0.00 & 0.79 & 0.31 \\
\hline Any Tangibles & 198 & 0.57 & 1.00 & 0.50 & 141 & 0.26 & 0.00 & 0.44 & $0 * * *$ \\
\hline Patenting Firm & 198 & 0.14 & 0.00 & 0.35 & 141 & 0.03 & 0.00 & 0.17 & $0 * * *$ \\
\hline Politician on Board & 198 & 0.29 & 0.00 & 0.45 & 141 & 0.33 & 0.00 & 0.47 & 0.38 \\
\hline
\end{tabular}

This article nrot cted by copyright. All rights reserved. 

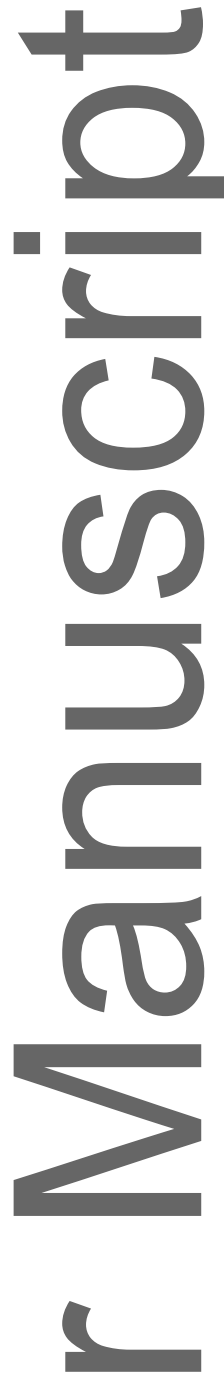

This article nrot cted by copyright. All rights reserved.

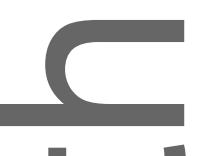


Table 3. IPOs by Industry

We group firms by industry, according to their classification by the Stock Exchange Daily OfficialList

\begin{tabular}{lccccc}
\hline & IPOs & Old-Tech & New-Tech & Domestic & Foreign \\
\hline Banks and Diseount Companies & 4 & 4 & 0 & 0 & 4 \\
Breweries and Distilleries & 13 & 13 & 0 & 12 & 1 \\
Commercial, Industrial, \&c. & 155 & 137 & 18 & 125 & 30 \\
Electric Lighting \& Power & 11 & 0 & 11 & 9 & 2 \\
Financial Land and Investment & 23 & 23 & 0 & 2 & 21 \\
Financial Trusts & 12 & 12 & 0 & 8 & 4 \\
Insurance & 7 & 7 & 0 & 7 & 0 \\
Iron, Coal and Steel & 20 & 20 & 0 & 20 & 0 \\
Mines & 8 & 8 & 0 & 0 & 8 \\
Nitrate & 3 & 3 & 0 & 0 & 3 \\
Oil & 11 & 11 & 0 & 0 & 11 \\
Railways & 10 & 9 & 1 & 5 & 5 \\
Shipping & 3 & 3 & 0 & 3 & 0 \\
Tea, Coffee and Rubber & 48 & 48 & 0 & 0 & 48 \\
Telegraphs and Telephones & 3 & 1 & 2 & 1 & 2 \\
Tramways and Omnibus & 6 & 0 & 6 & 5 & 1 \\
Water Works & 2 & 2 & 0 & 1 & 1 \\
\hline Total & 339 & 301 & 38 & 198 & 141 \\
\hline
\end{tabular}

Table 4. Regression of share applications on firm characteristics.

We regress share applications (\% of offered) and fully subscribed (which equals one if share applications is greater or equal to one hundred percent) on firm characteristics. p-values are reported in parentheses. $* * *, * *$, and $*$ denote significance at the $1 \%, 5 \%$, and $10 \%$ levels. Sample is trimmed at the 1st and 99th percentiles based on Underpricing.

\begin{tabular}{lcc}
\hline & $\begin{array}{c}\text { Share } \\
\text { Applications }\end{array}$ & $\begin{array}{c}\text { Fully } \\
\text { Subscribed }\end{array}$ \\
\hline Intercept & 0.387 & $1.254^{* * *}$ \\
Foreign Firm & $(0.614)$ & $(0.001)$ \\
New-Tech Firm & 0.010 & 0.066 \\
& $(0.930)$ & $(0.256)$ \\
Politician on Board & $-0.265^{*}$ & -0.101 \\
& $(0.097)$ & $(0.210)$ \\
& $-0.235^{* *}$ & $-0.094^{*}$
\end{tabular}

This is the author manuscript accepted for publication and has undergone full peer review but has not been through the copyediting, typesetting, pagination and proofreading process, which may lead to differences between this version and the Version of Record. Please cite this article as doi: 10.1111/ehr.12783.

This article is protected by copyright. All rights reserved. 


\begin{tabular}{|c|c|c|}
\hline Military on Board & $\begin{array}{l}-0.176 \\
(0.198)\end{array}$ & $\begin{array}{l}-0.117^{*} \\
(0.090)\end{array}$ \\
\hline Log (Auditor IPOs (\#)) & $\begin{array}{c}0.024 \\
(0.489)\end{array}$ & $\begin{array}{c}0.010 \\
(0.580)\end{array}$ \\
\hline Log (Lead Bank IPOs (\#)) & $\begin{array}{l}-0.025 \\
(0.502)\end{array}$ & $\begin{array}{l}-0.038^{*} \\
(0.044)\end{array}$ \\
\hline Underwritten & $\begin{array}{l}-0.090 \\
(0.366)\end{array}$ & $\begin{array}{l}-0.022 \\
(0.652)\end{array}$ \\
\hline Official Quotation Sought & $\begin{array}{l}-0.109 \\
(0.486)\end{array}$ & $\begin{array}{l}-0.058 \\
(0.463)\end{array}$ \\
\hline $\log (1+$ Track Record $)$ & $\begin{array}{l}-0.081 \\
(0.324)\end{array}$ & $\begin{array}{l}-0.028 \\
(0.491)\end{array}$ \\
\hline $\log (1+$ Firm Age $)$ & $\begin{array}{l}0.078 * \\
(0.058)\end{array}$ & $\begin{array}{l}0.039 * \\
(0.057)\end{array}$ \\
\hline $\log (1+$ Firm Size $)$ & $\begin{array}{c}0.021 \\
(0.705)\end{array}$ & $\begin{array}{l}-0.036 \\
(0.191)\end{array}$ \\
\hline$\%$ shares sold to public & $\begin{array}{l}-0.009 \\
(0.966)\end{array}$ & $\begin{array}{c}0.159 \\
(0.133)\end{array}$ \\
\hline Tangibles / Firm Size & $\begin{array}{c}0.120 \\
(0.249)\end{array}$ & $\begin{array}{c}0.065 \\
(0.217)\end{array}$ \\
\hline Patenting Firm & $\begin{array}{l}-0.071 \\
(0.657)\end{array}$ & $\begin{array}{l}0.142 * \\
(0.078) \\
\end{array}$ \\
\hline $\mathrm{R}^{2}$ & 0.087 & 0.120 \\
\hline $\mathrm{N}$ & 268 & 268 \\
\hline
\end{tabular}

\section{Table 5. Regressions of IPO Underpricing on firm characteristics}

We regress underpricing (\%) on characteristics as reported in the firm's prospectus in column one, and on characteristics and (realized) share applications as a percentage of offered shares in column two. $\mathrm{p}$-values are reported in parentheses. $* * *, * *$, and $*$ denote significance at the $1 \%, 5 \%$, and 10\% levels. Sample is trimmed at the 1 st and 99 th percentiles based on Underpricing.

\begin{tabular}{lcc}
\hline Intercept & 0.555 & 0.412 \\
Foreign Firm & $(0.105)$ & $(0.271)$ \\
& 0.076 & $0.098^{*}$ \\
New-Tech Firm & $(0.150)$ & $(0.079)$ \\
Politician on Board & 0.050 & 0.081 \\
& $(0.497)$ & $(0.294)$ \\
Military on Board & 0.030 & 0.048 \\
& $(0.535)$ & $(0.345)$ \\
& $-0.116^{*}$ & -0.087
\end{tabular}




\begin{tabular}{|c|c|c|}
\hline Log (Auditor IPOs (\#)) & $\begin{array}{l}-0.007 \\
(0.670)\end{array}$ & $\begin{array}{l}-0.013 \\
(0.428)\end{array}$ \\
\hline Log (Lead Bank IPOs (\#)) & $\begin{array}{c}0.002 \\
(0.913)\end{array}$ & $\begin{array}{l}-0.018 \\
(0.324)\end{array}$ \\
\hline Underwritten & $\begin{array}{c}-0.093 * * \\
(0.045)\end{array}$ & $\begin{array}{l}-0.084 * \\
(0.082)\end{array}$ \\
\hline Official Quotation Sought & $\begin{array}{c}0.063 \\
(0.350)\end{array}$ & $\begin{array}{c}0.038 \\
(0.619)\end{array}$ \\
\hline Log $(1+$ Track Record $)$ & $\begin{array}{l}-0.036 \\
(0.316)\end{array}$ & $\begin{array}{l}-0.007 \\
(0.870)\end{array}$ \\
\hline $\log (1+$ Firm Age $)$ & $\begin{array}{c}0.020 \\
(0.270)\end{array}$ & $\begin{array}{c}0.005 \\
(0.817)\end{array}$ \\
\hline $\log (1+$ Firm Size $)$ & $\begin{array}{l}-0.042 * \\
(0.092)\end{array}$ & $\begin{array}{l}-0.038 \\
(0.159)\end{array}$ \\
\hline$\%$ shares sold to public & $\begin{array}{l}-0.050 \\
(0.585)\end{array}$ & $\begin{array}{c}0.007 \\
(0.945)\end{array}$ \\
\hline Tangibles / Firm Size & $\begin{array}{c}0.098 * * \\
(0.043)\end{array}$ & $\begin{array}{c}0.073 \\
(0.151)\end{array}$ \\
\hline Patenting Firm & $\begin{array}{l}-0.002 \\
(0.980)\end{array}$ & $\begin{array}{c}0.046 \\
(0.550)\end{array}$ \\
\hline Share Applications (\% of Offered) & & $\begin{array}{c}0.048 * * * \\
(0.000)\end{array}$ \\
\hline $\mathrm{R}^{2}$ & 0.062 & 0.150 \\
\hline $\mathrm{N}$ & 326 & 268 \\
\hline
\end{tabular}

\section{Table 6. Long-run Performance}

We regress 3 year return (\%) on characteristics as reported in the firm's prospectus in column one, and on characteristics and (realized) share applications as a percentage of offered shares in column two. $\mathrm{p}$-values are reported in parentheses. $* * *, * *$, and $*$ denote significance at the $1 \%, 5 \%$, and $10 \%$ levels. Sample is trimmed at the 1 st and 99 th percentiles based on Underpricing.

\begin{tabular}{lcc}
\hline Intercept & -1.981 & -2.861 \\
Foreign Firm & $(0.169)$ & $(0.101)$ \\
& 0.338 & $0.462^{*}$ \\
New-Tech Firm & $(0.130)$ & $(0.077)$ \\
& 0.105 & 0.134 \\
Politician on Board & $(0.734)$ & $(0.711)$ \\
& -0.197 & -0.224 \\
Military on Board & $(0.333)$ & $(0.343)$ \\
& $-0.528^{* *}$ & $-0.738^{* *}$
\end{tabular}

This article is protected by copyright. All rights reserved. 


\begin{tabular}{|c|c|c|}
\hline & $(0.048)$ & $(0.018)$ \\
\hline \multirow[t]{2}{*}{ Log (Auditor IPOs (\#)) } & 0.008 & 0.000 \\
\hline & $(0.907)$ & $(1.000)$ \\
\hline \multirow[t]{2}{*}{ Log (Lead Bank IPOs (\#)) } & -0.041 & -0.115 \\
\hline & $(0.570)$ & $(0.179)$ \\
\hline \multirow[t]{2}{*}{ Underwritten } & $-0.374^{*}$ & $-0.432 *$ \\
\hline & $(0.054)$ & $(0.056)$ \\
\hline \multirow[t]{2}{*}{ Official Quotation Sought } & -0.157 & -0.219 \\
\hline & $(0.580)$ & $(0.536)$ \\
\hline \multirow[t]{2}{*}{ Log $(1+$ Track Record $)$} & -0.035 & 0.049 \\
\hline & $(0.817)$ & $(0.792)$ \\
\hline \multirow{2}{*}{$\log (1+$ Firm Age $)$} & $0.159 * *$ & $0.189 * *$ \\
\hline & $(0.039)$ & $(0.042)$ \\
\hline \multirow[t]{2}{*}{$\log (1+$ Firm Size $)$} & $0.201^{*}$ & $0.293 * *$ \\
\hline & $(0.056)$ & $(0.019)$ \\
\hline \multirow[t]{2}{*}{$\%$ shares sold to public } & $-0.655^{*}$ & -0.675 \\
\hline & $(0.093)$ & $(0.157)$ \\
\hline \multirow{2}{*}{ Tangibles / Firm Size } & -0.118 & -0.338 \\
\hline & $(0.562)$ & $(0.155)$ \\
\hline \multirow[t]{2}{*}{ Patenting Firm } & -0.220 & -0.305 \\
\hline & $(0.494)$ & $(0.398)$ \\
\hline \multirow[t]{2}{*}{ Share Applications (\% of Offered) } & & -0.006 \\
\hline & & $(0.883)$ \\
\hline $\mathrm{R}^{2}$ & 0.069 & 0.101 \\
\hline $\mathrm{N}$ & 326 & 268 \\
\hline
\end{tabular}

\section{(}

\section{Table 7. Individual share allotments and underpricing}

We regress the natural logarithm of an investor's number of allotted shares on Related Occupation (equal to one if the investor worked in the same industry as the firm and zero otherwise), Related Location (equal to one if the investor lived in the same geographical area as the firm and zero otherwise), and Underpriced. p-values are reported in parentheses. ***, $* *$, and $*$ denote significance at the $1 \%, 5 \%$, and $10 \%$ levels. Sample is trimmed at the $1 \mathrm{st}$ and 99th percentiles based on Underpricing.

\begin{tabular}{lcc}
\hline & Old Tech & New Tech \\
\hline Related Occupation & 0.019 & $-1.334^{* * *}$ \\
& $(0.633)$ & $(0.000)$ \\
Related Location & $0.164^{* *}$ & $-0.061^{* * *}$ \\
Related Occupation $\times$ Underpriced & $(0.031)$ & $(0.008)$ \\
& $0.152^{* * *}$ & $1.490^{* * *}$ \\
Related Location $\times$ Underpriced & $(0.003)$ & $(0.000)$ \\
& -0.030 & -0.081
\end{tabular}

This article is protected by copyright. All rights reserved. 


\begin{tabular}{lcc} 
& $(0.755)$ & $(0.578)$ \\
\hline $\mathrm{R}^{2}$ & 0.398 & 0.347 \\
$\mathrm{~N}$ & 76,949 & 6,907 \\
\hline
\end{tabular}

Notes: We use firm, occupation, and location fixed effects. Underpriced equals one if Underpricing is positive. We interact all fixed effects with Underpriced.

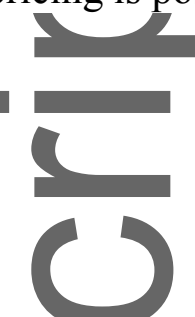

\section{Table 8. Individual share allotments and underpricing}

We regress the natural logarithm of an investor's number of allotted shares on Related Occupation (equal to one if the investor worked in the same industry as the firm and zero otherwise), Related Location (equal to one if the investor lived in the same geographical area as the firm and zero otherwise), and Underpriced. p-values are reported in parentheses. $* * *$, $* *$, and $*$ denote significance at the $1 \%, 5 \%$, and $10 \%$ levels. Sample is trimmed at the $1 \mathrm{st}$ and 99th percentiles based on Underpricing.

\begin{tabular}{lcc}
\hline & U.K. & Foreign \\
\hline Related Occupation & 0.034 & -0.005 \\
& $(0.495)$ & $(0.924)$ \\
Related Location & $0.143^{* *}$ & $0.712^{*}$ \\
& $(0.021)$ & $(0.057)$ \\
Related Occupation $\times$ Underpriced & $0.116^{*}$ & 0.102 \\
& $(0.072)$ & $(0.199)$ \\
Related Location $\times$ Underpriced & -0.018 & $-0.722^{*}$ \\
& $(0.835)$ & $(0.060)$ \\
\hline $\mathrm{R}^{2}$ & 0.367 & 0.337 \\
$\mathrm{~N}$ & 54,105 & 29,751 \\
\hline
\end{tabular}

Notes: We use firm, occupation, and location fixed effects. Underpriced equals one if Underpricing is positive. We interact all fixed effects with Underpriced.

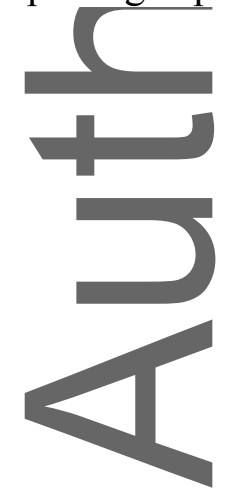


Table 9. Individual share allotments and long-run performance

We regress the natural logarithm of an investor's number of allotted shares on Related Occupation (equal to one if the investor worked in the same industry as the firm and zero otherwise), Related Location (equal to one if the investor lived in the same geographical area as the firm and zero otherwise), and 3 year return positive. p-values are reported in parentheses. $* * *, * *$, and $*$ denote significance at the $1 \%, 5 \%$, and $10 \%$ levels. Sample is trimmed at the 1st and 99th percentiles based on Underpricing.

\begin{tabular}{lcc}
\hline & Old Tech & New Tech \\
\hline Related Occupation & 0.057 & 0.103 \\
& $(0.119)$ & $(0.622)$ \\
Related Location & $0.102^{*}$ & $-0.359^{* * *}$ \\
& $(0.094)$ & $(0.000)$ \\
Related Occupation $\times 3$ year return positive & $0.126^{* *}$ & -0.086 \\
& $(0.035)$ & $(0.819)$ \\
Related Location $\times 3$ year return positive & 0.097 & $0.746^{* * *}$ \\
& $(0.213)$ & $(0.000)$ \\
\hline $\mathrm{R}^{2}$ & 0.397 & 0.361 \\
$\mathrm{~N}$ & 76,949 & 6,907 \\
\hline
\end{tabular}

Notes: We use firm, occupation, and location fixed effects. 3 year return positive equals one if 3 year return is positive and zero otherwise. We interact all fixed effects with 3 year return positive.

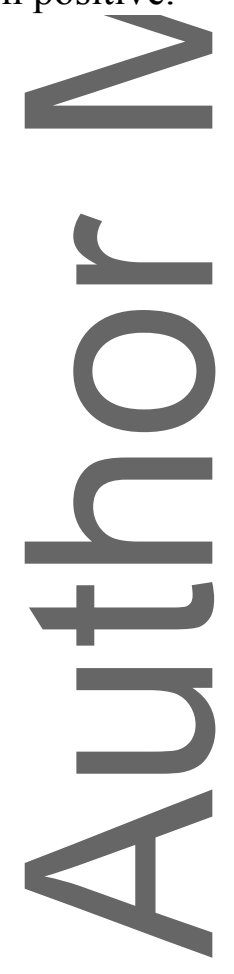


Table 10. Individual share allotments and long-run performance

We regress the natural logarithm of an investor's number of allotted shares on Related Occupation (equal to one if the investor worked in the same industry as the firm and zero otherwise), Related Location (equal to one if the investor lived in the same geographical area as the firm and zero otherwise), and 3 year return positive. Sample is trimmed at the 1st and 99th percentiles based on Underpricing.

\begin{tabular}{lcc}
\hline & U.K. & Foreign \\
\hline Related Occupation & 0.056 & 0.022 \\
& $(0.254)$ & $(0.667)$ \\
Related Location & 0.061 & -0.014 \\
& $(0.405)$ & $(0.912)$ \\
Related Occupation $\times 3$ year return positive & 0.094 & 0.121 \\
& $(0.206)$ & $(0.175)$ \\
Related Location $\times 3$ year return positive & $0.148^{*}$ & 0.245 \\
& $(0.086)$ & $(0.268)$ \\
$\mathrm{R}^{2}$ & 0.367 & 0.335 \\
$\mathrm{~N}$ & 54,105 & 29,751 \\
\hline
\end{tabular}

Notes: We use firm, occupation, and location fixed effects. 3 year return positive equals one if 3 year return is positive and zero otherwise. We interact all fixed effects with Underpriced.

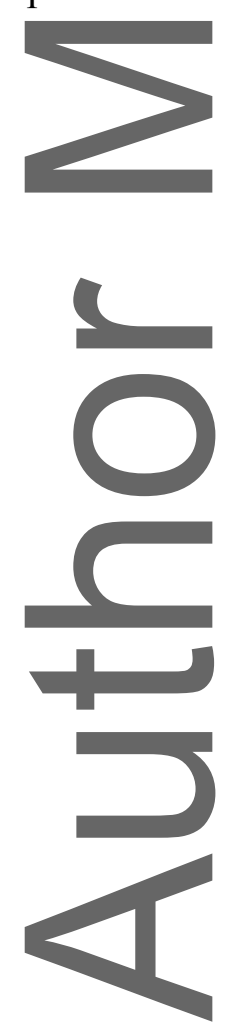




\section{University Library}

\section{- M M I N E R VA A gateway to Melbourne's research publications}

Minerva Access is the Institutional Repository of The University of Melbourne

Author/s:

Fjesme, S;Galpin, N;Moore, L

Title:

An efficient market? Going public in London, 1891-1911

Date:

2019-08-01

Citation:

Fjesme, S., Galpin, N. \& Moore, L. (2019). An efficient market? Going public in London, 1891-1911. Economic History Review: a journal of economic and social history, 72 (3), pp.1008-1027. https://doi.org/10.1111/ehr.12783.

Persistent Link:

http://hdl.handle.net/11343/284491 